\title{
Judicial Protection of Human Rights in Post-Conflict Burundi: Gap Between Legal Principles and Practices
}

\author{
Aimé-Parfait Niyonkuru*
}

\begin{abstract}
This paper aims to discuss the issue of the judicial protection of human rights in post-conflict Burundi. In doing so, it provides some insights into Burundi's legal and institutional framework. It further assesses this framework through the prism of the efficiency of institutional safeguards provided for by this framework, particularly the judiciary, as the cornerstone, both of human rights protection and of rule of law. While recognizing some merits of this framework, this reflection focuses on the main challenges faced by post-conflict Burundi's judicial system in the protection of human rights. It argues that while it is far from perfect, Burundi's legal framework is progressive and likely to ensure respect and protection of the human rights, provided there is positive and courageous enforcement by independent and competent judges. Given the current state of affairs, however, Burundi's judiciary is institutionally too weak to properly perform its constitutional duty, especially with regards to its role of custodian of the citizen's rights and freedoms. ${ }^{1}$ The paper suggests, accordingly, that this weakness is more a result of the lack of independence of the judiciary and the failure to adhere to the rule of law in practice, rather than a consequence of a legal vacuum of human rights protection.
\end{abstract}

\section{Introduction}

"The greatest value of human life is best represented in the recognition of fundamental rights, and in fully enabling people to enjoy and exercise these rights to the extent that preserves their humanity and respects their civility. (...).The rights of individuals would be without value if no legal system were able to play an active role in their protection".

Fahed Abul-Ethem ${ }^{2}$

* Aimé-Parfait Niyonkuru (Ph.D in Law, KU Leuven, 2016) is a lecturer at the University of Burundi. Since October 2013, he is an accredited lawyer with the Burundian Bar Association (BBA). Since February 2017, he is a Phillip Schwartz Fellow at the Arnold-Bergstraesser-Institute in Freiburg, Germany. E-mail: niyoparfait2004@yahoo.fr or aime-parfait.niyonkuru@abi.uni-freiburg.de.

1 Constitution of the Republic of Burundi (2005), article 60.

2 Abul-Ethem, Fahed 'The role of the Judiciary in the Protection of Human Rights and Development: A Middle Eastern Perspective', 26 Fordham Int'l L.J. 761 (2002). Available at: http://ir.lawnet.fordh am.edu/ilj/vol26/iss3/8 [last accessed 16 November 2017]. 
During the 2000s, key political stakeholders in Burundi signed the Arusha Peace and Reconciliation Agreement (APRA) ${ }^{3}$ and the parties then at war concluded, later, the $2003^{4}$ and $2006^{5}$ Ceasefire Agreements, both agreements presented as having put an end to a decadelong civil war. Furthermore, given that since 2005, following the implementation of the power-sharing agreements, ${ }^{6}$ elected institutions emerging from post-transition elections replaced transitional regimes, the question of the protection of human rights continues to remain relevant. Omar Noman rightly writes that "problems of human rights are not resolved because an electoral system has replaced an authoritarian government", ${ }^{7}$ and he argues that it is common for human rights violations to continue to occur under elected regimes. ${ }^{8}$ In this regard, post-conflict Burundi is an interesting case-study.

This paper is divided into three major sections. The first section provides brief background information on Burundi's post-conflict context. The second gives an overview of human rights issues in post-conflict Burundi with a focus on patterns of violations and abuses of these rights. It also sheds light on the Burundi's current legal and institutional framework for human rights. The third section assesses the ability of Burundi's judicial system to effectively address human rights issues. Through this assessment, the final section examines - some of the - major challenges to effective judicial protection of Human Rights in the country.

\section{Background}

This section provides a brief background and the general information necessary for the best understanding of the issue under analysis, by situating the problem in its context. The background starts with a short presentation of Burundi's violent past (1). While, for the purpose of addressing the current issue, the paper assumes that Burundi is a post-conflict country, it nevertheless questions the relevance of this characterization (2), particularly given the magnitude and consequences of the political and humanitarian crisis that erupted in 2015, after the incumbent president Pierre Nkurunziza was nominated by his ruling Conseil National

3 Endorsed by Act No. 1/017 of December 1 ${ }^{\text {st }}$, 2000, Official Gazette of Burundi, No. 12 quater, 1147.

4 That is the Global Ceasefire Agreement (GCA) between the Transitional Government of Burundi and the National Council for the Defense of the Democracy-Forces for the Defense of Democracy (CNDD-FDD) of November 16, 2003 (endorsed by Act No. 1/023 of November 21, 2003, Official Gazette of Burundi, No. 11Bis, 781).

5 This agreement (Comprehensive Ceasefire Agreement Between the Government of the Republic of Burundi and the PALIPEHUTU-FNL of September 7, 2006) has not been endorsed by any law.

6 The three major agreements including provisions for power-sharing are the 2000 APRA and the 2003 and 2006 Ceasefire agreements (cf. note 4 and 5).

7 Noman, O., Responsible Development: Vulnerable Democracies, Hunger and Inequality, Routledge, 2010, 109.

8 Ibid. 
pour la Défense de la Démocratie-Forces de Défense de la Démocratie (CNDD) ${ }^{9}$ party to run for a controversial third term in office.

\section{Burundi's violent past}

Burundi, is a small $\left(27,834 \mathrm{~km}^{2}\right)$, overpopulated (ca. 12 million $)^{10}$ and landlocked country in Africa's Great Lakes Region. It is bordered by the Democratic Republic of the Congo (West), Rwanda (North), and Tanzania (East and South-East). Burundi is considered to belong to both East and Central Africa. From the partition of Africa into European spheres of influence at the 1884-1885 Berlin Conference until June 1916, when Belgian forces captured Usumbura from German control, the multi-secular kingdom of Burundi was a German protectorate within the "Schutzgebiet" Deutsch-Ostafrika. The country gained independence from Belgium on July 1, 1962. The royal system was overthrown in 1966 by a military coup led by Capt. Michel Micombero who later proclaimed the country a republic, abolishing the monarchy. ${ }^{11}$ In the decades that followed its independence, Burundi shifted into ethno-political based cycles of violence, which resulted in large-scale human rights violations (1965, 1969, 1972, 1988, 1991, 1993-2006, 2015). In this dynamic of violence, $1972^{12}$ and $1993^{13}$ are remembered as particularly bloody years, with some sources suggesting a "genocidal" character to the killings. ${ }^{14}$ After the abolition of the monarchy

9 National Council for the Defense of Democracy-Forces for the Defense of Democracy.

10 Burundi is one of the most densely populated country in Africa, with 421.9 people per square kilometer (June 2017).

11 Bulletin Officiel du Burundi (Official Gazette of Burundi)., 1967, 1; Bellon Remi and Delfosse, Pierre, Codes et Lois du Burundi, 1970, 7.

12 In 1972, following a Hutu rebel attack in the southern and western part of Burundi, where thousands of members of the Tutsi minority members were massacred, disproportionate government reprisals resulted in mass killings where thousands of Hutu lost their lives, with most of victims belonging to the more educated and socially prominent representatives of the group. See inter alia, Chrétien, J.-P., Du Pasquier, J.-Fr. (2007), E.-Eggers/ W. Weinstein, (1997).

13 In 1993, the assassination of the Burundi's first democratically elected President, Melchior Ndadaye (Hutu) by members of the then Tutsi-dominated military, was followed by ethno-political violence during which more than 300,000 lives are reported to have been lost. On the meaning of the terms ' hutu' and 'tutsi', see note 15.

14 Chrétien, J.-P., Du Pasquier, J.-Fr.., Burundi 1972. Au bord des génocides, Khartala, 2007; Lemarchand, R., "The Burundi genocide", in Totten, S., Parsons, W.- S., Charny, I.- W. (Eds.), Century of Genocide: Critical Essays and Eyewitness Accounts, $2^{\text {nd }}$ Ed., Routledge, London/ Newyork, 2004; Report of the assessment mission on the establishment of an international judicial commission of inquiry for Burundi (Kalomoh Report) in S/2005/158 of 11 March 2005; Lemarchand, R., "Le Génocide de 1972 au Burundi : Les Silences de l'Histoire", Cahiers d'Études africaines, 167/XLLII-3, 2002, pp. 551-567. Whitaker, B., Revised and Updated Report on the Question of the Prevention and Punishment of the Crime of Genocide (United Nations document E/CN. 4/Sub. 2/1985/6); Lemarchand, R.; Burundi: Ethnic Conflict and Genocide, New York: Woodrow Wilson Center Press and Cambridge University Press, 1994; Lemarchand and Martin, Selective Genocide in Burundi, London, Minority Rights Group, 1974. 
consecutive military regimes continued until 1993 when, for the first time since independence, democratic and free presidential and legislative elections, within a multi-party context were organized. On 21 October, 1993, after only 100 days in power, the first democratically elected Hutu ${ }^{15}$ President, Melchior Ndadaye was assassinated, with many of his close collaborators, in a "failed"16 military coup d'Etat. This attack on democracy, accompanied by serious human rights violations by Burundi's security forces, led in June 1994 to the creation of a Hutu-dominated rebel group, the CNDD which fought against the Tutsi-dominated government army responsible for the coup attempt and assassination of President $\mathrm{Nda}$ daye. Thus a civil war begun. At least 300,000 people were killed during this war marked by ethno-political violence. A war that ended through internationally mediated negotiations. Since 2005, a post-transition Constitution has been promulgated, with the holding of democratic elections at different levels ("colline" or hill, neighbourhood, commune and national). The former rebel movement, the CNDD-FDD, was transformed into a political party, which overwhelmingly won the elections and became the ruling party.

\section{Burundi: A post-conflict country?}

"Attaining durable peace (DP) after a civil war has proven to be a major challenge, as many negotiated agreements lapse into violence."

Druckman, D. Wagner, L. ${ }^{17}$

After roughly 15 years of civil war (1993-2008), Burundi entered a new phase of negotiated post-conflict governance based on a complex power-sharing formula as a prime example of institutional engineering ${ }^{18}$. With the signing of the 2000 Arusha Peace and Reconciliation

15 The population of Burundi is divided into three major ethnic groups: the Hutu, the Tutsi and the Twa. Figures from a 1956 colonial-era census, extrapolated by most scholars, experts and other analysts until to the present, indicate that the Hutu are the largest of the three ethnic groups ( 85 percent), followed by Tutsi (14 percent) and Twa (1 percent).

16 There is a controversial discussion on the coup. While one opinion suggest a mere coup attempt insofar as the army did not seize power nor directly appoint a successor to Ndadaye, a divergent opinion argues that the 1993 coup was successful as it led to the unconstitutional replacement of an elected figure by non-elected institutions, these latter comprising politicians who had lost the 1 and 29 June 1993 respective presidential and parliamentary elections, both overwhelmingly won by Ndadaye's Frodebu [Front pour la Démocratie au Burundi] party.

17 Druckman, D. and Wagner, L. "Justice Matters: Peace Negotiations, Stable Agreements, and Durable Peace", Journal of Conflict Resolution, published: November 13, 2017 (https://doi.org/10. 1177/0022002717739088).

18 Reyntjens, P., 'Institutional Engineering, Management of Ethnicity, and Democratic Failure in Burundi', 51Africa Spectrum, 2 (2016), 65-78; Vandengiste, St., 'Power-Sharing, Conflict and Transition in Burundi: Twenty Years of Trial and Error', 44 Africa Spectrum, 3 (2009), 63-86; Falch, A. and Becker, M., 'Power-sharing and Peacebuilding in Burundi. Power-sharing Agreements, Negotiations and Peace Processes', http://www.prio.no/CSCW/Research-and-Publications/Project/?oid= 65122 . 
Agreement for Burundi and the subsequent 2003 and 2006 Ceasefire Agreements, Burundi has been presented as an example of successful negotiated power-sharing arrangements leading to the settlement of a protracted civil war. However, despite numerous studies and newspaper articles that have described Burundi as a success story ${ }^{19}$ of a negotiated transition to peaceful governance through power sharing between the Hutu and Tutsi communities, Burundi has not enjoyed a high level of political stability.

If peace is understood "negatively" as the absence of war, then it can be argued that it has prevailed in Burundi, at least since the Ceasefire agreement between Burundi's government and the then FNL [Front National de Libération]-Palipehutu, the last active rebel group, was signed in 2006 or at the latest since the FNL officially laid down its arms and its leaders were appointed to civil service positions, with the combatants being integrated into the national army and police in 2009 . Nonetheless, political violence, ${ }^{20}$ including "state violence" ${ }^{21}$ has persisted. If, as noted here, some scholars have been painting Burundi as a case of successful transition from war to peace, another opinion is more nuanced: rather than seeing an immaculate peace process transition, leading to durable peace, some analysts have argued that the peace which post-conflict Burundi has experienced is vulnerable. ${ }^{22}$ Some have concluded in or predicted a failure of peace, ${ }^{23}$ believing only in the "confined success of the Burundian power-sharing agreements" 24 or have questioned the durability of the Arusha Peace and Reconciliation Agreement ${ }^{25}$ for Burundi. ${ }^{26}$ The message is clear, the future of the peace in post-conflict Burundi is uncertain. This is particularly true when taking into account the recent turmoil following President Pierre Nkurunziza's controversial nomination to stand for a third term in office and the holding of the 2015 contested elections. Since the country has experienced serious political unrest since then, one may

19 Uvin, P., Life after Violence: A People's Story of Burundi; Zed Books LTD, London, 2009; Boshoff, H., Very, W. and Rautenbach, G., The Burundi peace process: From civil war to conditional peace, Pretoria : Institute for Security Studies, 2010, 69; Peen Rodt, A., 'The African Union Mission in Burundi: The Successful Management of a Violent Ethno-Political Conflict?', 10 Ethnopolitics Papers, May 2011, 18; Devon Curtis; The international peacebuilding paradox: Power sharing and post-conflict governance in Burundi, 112 African Affairs, 446 (2013), 72-91.

20 International Crisis Group, 'Burundi: Bye-Bye Arusha?', Rapport Afrique $\mathrm{N}^{\circ} 192-25$ October 2012.

21 Ibid.

22 Curtis, D. and Nindorera, W. 'A Vulnerable Peace: What's at Stake in the Upcoming Burundian Elections', The Global Observatory, February 20, 2015, available at https://theglobalobservatory.o $\mathrm{rg} / 2015 / 02 /$ vulnerable-peace-burundi-elections-nkurunziza/ [last accessed 6 October 2017].

23 Sullivan, Daniel P., 'The Missing Pillars: A Look at the Failure of Peace in Burundi through the Lens of Arend Lijphart's Theory of Consociational Democracy', 43 The Journal of Modern African Studies, 1 (2005), 75-95.

24 Falch, A. and Becker, M., 'Power-Sharing and Peacebuilding in Burundi. Negotiations and Peace Processes'.

25 Cf. note 3.

26 All Africa, 'Burundi: Is the Arusha Peace Treaty Under Threat?', available at http://allafrica.com/v iew/group/main/main/id/00038547.html [last accessed 6 October 2017]. 
question whether the qualification of Burundi as a post-conflict country is still appropriate. As a matter of fact, the nomination of the incumbent president by his party (CNDD-FDD) on 26 April, 2015, to run for the presidential election scheduled for 26 June $2015^{27}$ triggered a grave political and humanitarian crisis. This nomination sparked mass protest across Bujumbura, the capital and in some provinces, ${ }^{28}$ which were followed by a bloody crackdown ${ }^{29}$ by Burundi's defense and security forces, the National Intelligence Services and the ruling party youth (Imbonerakure i.e "those who see far" in Kirundi). ${ }^{30}$

Since the start of the 2015 crisis, sources report that at least a thousand people have been killed, ${ }^{31}$ nearly a thousand have become victims of forced disappearances ${ }^{32}$ and some 420,000 Burundians have fled to neighbouring countries. ${ }^{33}$

The risk for the country to relapse into another violent conflict is therefore entirely plausible. In this regard, it is not superfluous to point out that as a consequence of the 2015 crisis, at least two new armed rebellions surfaced, namely the Forces Républicaines $d u$ Bu-

27 This election was finally postponed and was held on 21 July 2015. Likewise, parliamentary and local elections, which were initially scheduled for 26 May 2015, were held on 29 June, 2015.

28 African Commission on Human and Peoples' Rights, Report of the Delegation of the African Commission on Human and Peoples' Rights on its Fact-Finding Mission to Burundi, 7-13 December 2015, para.41, 45 .

29 In their 2016 Reports, FIDH and Ligue Iteka evoke the severity of the Nkurunziza regime's response to protesters "Merciless repression of demonstrations: From brutal violence to massacre", November $2016 / \mathrm{N}^{\circ} 685 \mathrm{a}, 25$.

30 FIDH, 'Repression and pre-genocidal dynamics in Burundi', Report, November 2016 / №685a. See also: Human Rights Watch, World Report 2017:Events of 2016, 157-163, available at: https:// www.hrw.org/sites/default/files/world_report_download/wr2017-web.pdf [last accessed 6 October 2017]; Amnesty International, 'Conform or Flee. Repression and insecurity pushing Burundians into exile', 2017.

31 ICC, 'ICC judges authorise opening of an investigation regarding Burundi situation', Press Release, 9 November 2017; La Libre Belgique, 'Burundi: le régime veut contrôler de plus en plus la population', December 28, 2016. Available at: http://www.lalibre.be/actu/international/burundi-leregime-veut-controler-de-plus-en-plus-la-population-5862ba69cd7014981b403c2a [last accessed 9 October 2017]; 'Le Burundi menace de porter plainte contre le Rwanda devant l'ONU', Info Grands Lacs, June 29, 2017. Available at: http://www.infosgrandslacs.info/productions/le-burundi -menace-de-porter-plainte-contre-le-rwanda-devant-lonu [last accessed 9 October 2017]; 'Burundi : «Le seul film dont il faut empêcher la sortie», France 24, November 17, 2016. Available at: http://www.france24.com/fr/20161116-burundi-fidh-derives-film-campagne-communication-rappo rt [last accessed 9 October 2017]; Nkurunziza, J.-B. and Anyandike, O., 'Briefing - who's who in Burundi's armed opposition. With no peace talks on the cards, the threat of civil war grows', IRIN, 7 June 2016. Available at: http://www.irinnews.org/analysis/2016/06/07/briefing-\%E2\%80\%93-w ho $\%$ E2\%80\%99s-who-burundi\%E2\%80\%99s-armed-opposition [last accessed 30 October 2017].

32 'Burundi on the brink: looking back on two years of terror', International Federation for Human Rights, June 2017, $\mathrm{N}^{\circ}$ 693a, available at: http://www.refworld.org/docid/595cd7a74.html [accessed 14 November 2017].

33 UNHCR, 'Burundi Situation 2017: Supplementary Appeal January- December 2017 (May 2017), Burundian refugees and asylum seekers in neighbouring countries as of 30 April 2017, May 2017, http://www.unhcr.org/59244aa77.pdf [last accessed 6 October 2017]. 
rundi (Forebu) and the Résistance pour un Etat de droit au Burundi (RED-Tabara) and openly declared war on Burundi's government whose organs and agents they accused of committing crimes against the population. These two rebel groups came to lengthen the list of armed groups vowing to drive out Nkurunziza by force "to protect the population", 34 if one takes into account the Forces Nationales pour la Libération (FNL). Still, following the 2006 ceasefire agreement, the FNL officially laid down its arms in 2009, leading to its recognition as a legal political party. Yet, in September 2012, a dissident group of FNL combatants commanded by Aloys Nzabampema -opposed to the historic leader Agathon Rwasa - resumed armed hostilities against the Burundi government. It mainly operates in the Ruzizi river plain, mostly using the Democratic Republic of the Congo's South Kivu province as a rear base for organizing, planning, training and launching operations across the border into Burundi. ${ }^{35}$

Given that the political context is so fluid and peace so fragile, any assumption of a stable post-conflict order permitting a consistent reform of the justice system may be premature.

\section{Burundi's Human Rights Legal Framework: A progressive and promising legal framework}

"Human Rights promotion and protection remains one of the greatest challenges for Burundi. (...) in spite of the efforts made by different actors in the field, (...) national institutions that safeguard the respect for rule of law and human rights are weak. "36

This section provides a brief overview of the status of human rights in the domestic legal system. It argues that Burundi provides one of the highest protective legal frameworks worldwide.

As far as judicial protection of human rights is concerned, it is worth noting that Burundi has one of the most progressive legal system in Africa, and perhaps in the world. However, the major challenge of effective protection of human rights, including judicial protection, is far from being a matter of an inappropriate legal framework. Of course, with respect

34 Shemeza, 'Burundi: We are ready for war-Burundi's rebel groups and how they plan to topple president Nkurunziza', Burundi News, March 2, 2017. Available at: http://www.shemezaclouds.co $\mathrm{m} /$ burundi-we-are-ready-for-war-burundis-rebel-groups-and-how-they-plan-to-topple-president-nk urunziza/ [last accessed 14 November 2017]; Rukundo, Yv., 'Burundi: 3 groupes armés résolus à déloger Nkurunziza par la force', Agence Anadolu, 2017. Available at: http://aa.com.tr/fr/afrique/b urundi-3-groupes-arm $\% \mathrm{C} 3 \% \mathrm{~A} 9 \mathrm{~s}-\mathrm{r} \% \mathrm{C} 3 \% \mathrm{~A} 9$ solus- $\% \mathrm{C} 3 \% \mathrm{~A} 0$-d $\% \mathrm{C} 3 \% \mathrm{~A} 9$ loger-nkurunziza-par-la-f orce-encadr\%C3\%A9-/510498 [last accessed 14 November 2017].

35 See the Final Report of the UN Group of Experts on the Democratic Republic of the Congo, S/ 2015/19 (2015).

36 Government of Burundi, United Nations Integrated Office in Burundi (BINUB), Office of the High Commissioner for Human Rights (OHCHR),United Nations Development Programme (UNDP), United Nations Children's Fund (UNICEF), Human Rights and Justice Joint Programme. 
to the -judicial- protection of human rights, as well as other related issues, Burundi's legal framework is far from perfect. Some insufficiencies and inconsistencies do exist. This paper argues however that the existing legal framework has significant potential, but it requires the full and fair implementation by an impartial and independent judiciary, by judges with sufficient professional qualifications and resistance to corruption, in order to enhance effective protection and redress for victims of human rights violations.

From a strict normative point of view, Burundi has an impressive human rights framework. Interestingly, human rights have been constitutionalized and major human rights treaties ratified. So far as the constitutionalisation of human rights is concerned, not only does Burundi's Constitution reserve a chapter for individuals' and citizen's fundamental rights, ${ }^{37}$ but also the list of human rights with a constitutional status is lengthened by the constitutionalisation of international human rights proclaimed and guaranteed by relevant international human rights instruments. ${ }^{38}$ Both of these two aspects of constitutionalisation are of a central importance in the judicial protection of human rights. This is because the constitutionalised human rights are provided with the strongest normative status within the domestic legal order. Last but not least, from the angle of justiciability, the two abovementioned aspects of constitutionalisation of human rights empower individuals to challenge the courts -the judicial power in general and the Constitutional Court in particular ${ }^{39}-$ human rights proclaimed and guaranteed by human rights instruments whose rights are enshrined within them are an integral part of the Burundi's Constitution by virtue of article 19. This justiciability applies regardless of the status of international law in Burundi's - domestic - legal order. ${ }^{40}$ In this regard, Justice Fatsah Ouguergouz believes that "there is no need to discuss (...) the two main theories relating to the relationship between the munici-

\section{Article 21 to 61 .}

38 Stressing the fact that the list is merely illustrative and not exhaustive, article 19 provides that "Rights (...) proclaimed and guaranteed, among others, by the Universal Declaration of Human Rights, the [two 1966] International Covenants on Human Rights, the African Charter on Human and Peoples' Rights, The Convention on the Elimination of All Forms of Discrimination against Women and the Convention on the Rights of the Child are an integral part of the Constitution of the Republic of Burundi". Interestingly, this provision adds that: "These fundamental rights are not subject to any restriction or derogation, except in certain circumstances justifiable by the general interest or the protection of a fundamental right.".

39 Interestingly, Burundi's Constitutional Court can be seized by an individual upon matters dealing with human rights, either directly by course of action, or indirectly by the procedure of the exception of unconstitutionality invoked in a matter brought before a court of law (pursuant to Burundi's Constitution of the Republic of Burundi of 2005, art. 230, apart from individuals, the Burundi's Constitutional Court can be seized by the President of the Republic, the President of the National Assembly (the lower house of parliament), the President of the Senate (the upper house), one quarter of members of the National Assembly, one quarter of senators and the Ombudsman).

40 Traditionally, the problem of the incorporation of international law into a domestic legal order relies on two theories: monism and dualism. Nigel Foster made an interesting synthesis of the two theories. According to this author, "Monism basically assumes that international law and national law form part of a single system of laws; therefore, the acceptance of international law would not require formal incorporation by legislative transformation, but after treaty agreement and assent or 
pal and the international legal orders; that is to say, Monism and Dualism. Suffice to say that (...) the Constitution of Burundi provides that the rights and duties proclaimed [among others] by the International Bill of Human Rights and the African Charter on Human and peoples' Rights shall be an integral part of the Constitution." 41

Nevertheless, the merits of Burundi's legal framework, with respect to the judicial protection of human rights should not hide any legal loopholes limiting accountability of top officials for possible human rights violations and abuses. On this point, it is important to emphasize the fact that, despite Burundi's Constitution which provides for equality before law and equal protection of law; ${ }^{42}$ a short list of top state officials, namely the President of the Republic, the two vice-presidents of the Republic, the Speaker of the National Assembly and the Speaker of the Senate, cannot be held accountable before domestic courts, for any wrongful act, including serious violations of human rights. This lack of accountability derives from a deliberate legal loophole. While Burundi's Constitution since $1992^{43}$ provides for a High Court of Justice, currently competent to prosecute and judge the five top officials ${ }^{44}$ listed above, the same Constitution further provides for the establishment of an organic act governing the Court's organization, functioning as well as the procedure applicable before it. ${ }^{45}$ So far, this act has not yet been established. Accordingly, the five Burundi's top official would enjoy, if applicable, a de jure impunity, to the great displeasure of victims of human rights violations and abuses which those authorities could be alleged to be responsible for.

Except for this legal loophole, which is likely to darken Burundi's legal framework with respect to protection and redress for victims of human rights violations and abuses, one may argue, on the basis of the abovementioned arguments on the status of human rights in the domestic legal system, that Burundi's legal framework has an excellent foundation which an independent, professional and not under-funded judiciary can rely on, to hold perpetrators of human rights violations accountable for their acts, and to provide adequate redress to victims of these violations. However, the law's promises with respect to the judicial protection of human rights, are considerably limited by many challenges usually extending

ratification, (...) it would be directly applicable within the state". Burundi is an example of a monist state. "Dualism; on the other hand, regards international law and national law as fundamentally different systems of law that exist alongside each other. In order to overcome the barrier existing between the two systems, legislation is required to transform rules of international laws into the national legal system before it can have any binding effect within the state in such circumstances." Nigel Foster gives as examples of dualist states Great Bitain and Germany (Foster on EU Law, Oxford University Press, 2017, 150.

41 Ouguergouz, Fatsah, The African Charter of Human and People's Rights: A Comprehensive Agenda for Human Dignity and Sustainable Democracy in Africa, Martinus Nijhoff Publishers, 2003, 51-52.

42 Constitution of the Republic of Burundi (2005), art. 22.

43 Constitution of the Republic of Burundi (1992), art. 157.

44 Constitution of the Republic of Burundi (2005), art. 234.

45 Constitution of the Republic of Burundi (2005), art. 236. 
beyond the legal sphere. The following section discusses the most prominent of these challenges.

\section{Challenges to judicial protection of human rights in post-conflict Burundi}

It is well known that a strong, trustworthy, independent, impartial and competent judiciary established by law, is a cornerstone of the domestic mechanisms for the protection of human rights in any modern democracy. In the case of Burundi, the judicial mechanism faces many challenges with respect to effective protection of human rights. From my own assessment, the major challenges are the following: limits to or a lack of independence (1), failure of adherence to or weakness of rule of law (2) and an extreme passivity on the part of judges in applying domesticated international human rights law provisions (3).

\section{Inadequate judicial independence}

"The executive branch's ascendancy over the judicial branch is also apparent in the appointment of judges and the fact that they may be transferred, which runs counter to the principle of the irremovability of judges. The Ministry of Justice controls the promotion of judges and may propose their suspension or dismissal"

\section{Commission of Inquiry on Burundi ${ }^{46}$}

One of the biggest and most chronic challenges to access to justice in Burundi, repeatedly pointed out by nearly all reports and thematic studies, survey findings, etc. is the lack of independence of Burundi's judiciary. And without an independent judiciary, it is simply impossible for the courts to properly perform their function of guardian of human rights and freedoms.

Still, the independence of the judiciary and the judges are set out in Burundi's legal instruments, at the highest normative level. Basic principles of judicial independence are laid down in the Constitution and in laws enacted to implement it. For example, article 209 of Burundi's Constitution provides that "The judiciary shall be impartial and independent from the executive and legislature. In the exercise of its functions, the judge shall not be subject to any authority other than the Constitution and the law". In the same vein, article 29 of the 2000 law reforming the Status of Burundi's Magistrates states that "In the exercise of his functions, the judge is independent from the legislature and the executive and is only subject to law. He sovereignly assesses cases he is assigned, free of any influence." ${ }^{47}$ Yet, despite the abovementioned constitutional and legal guarantees, independence of the

46 Human Rights Council, Report of the Commission of Inquiry on Burundi, Report A/HRC/36/54 of 11 August 2017.

47 « Dans l'exercice de ses fonctions, le Magistrat assis est indépendant des pouvoirs législatif et exécutif et n'est soumis qu'à la loi. Il apprécie souverainement les causes dont il est saisi et décide de la suite à leur donner indépendamment de toute influence». 
judiciary does not exist beyond the letter of the law and those positive and ambitious statements.

The issue of independence of the judiciary is a truly multi-facetted question. The current sub-section does not intend to provide an-in-depth analysis of the issue of independence of the Burundi's judiciary, from a comprehensive legal perspective. ${ }^{48}$ Rather, using a basic overview of Burundi's legal framework, this section rather examines some inconsistencies and vacuums in the legal framework that are likely to pave the way for undue interference into the functioning of courts and undue influence over their decisions. Through a legal-institutional lens, this sub-section focuses on some inconsistencies and lacuna that limit independence of the judiciary and severely impedes the judicial protection of human rights and freedoms, accordingly. Aspects related to the recruitment, appointment, promotion, removal and transfer of judges from office, conditions of tenure as well as resources devoted to justice and Courts administration are discussed.

While decisions concerning the professional career of judges should be based on objective and transparent criteria, the selection and career of Burundi's judges are de facto not always based on merit, taking into account, among others factors, academic qualifications, personal integrity, professional abilities and technical efficiency. The 2000 Law on the Status of Magistrates set out basic requirements for candidates to the magistracy (article 4). It further specifies requirements for final appointment as a career magistrate, namely, "having served as magistrate under provisionary status for at least two years" and "being awarded a favorable End-of-Training Report". Lastly, if it is necessary to choose between candidates, the said law provides for a test organized by the Minister of Justice, in collaboration with the Superior Council of Magistracy (Conseil Supérieur de la Magistrature) ${ }^{49}$ However, except for the period 2014-2015, when magistrates -those of the primary courts excludedwere selected by means of competitive examinations, recruitment has operated at the discretion of the Minister of Justice. ${ }^{50}$

48 On this issue, see among others, Ntahiraja, B., 'L'indépendance du juge pénal au Burundi: Les défis actuels', KAS African Law Study Library, Vol. 3 (2016), 433; Niyonkuru, A.-P., 'L'accès au juge civil en droit burundais: Approche juridico-institutionnelle', Unpublished Ph.D Thesis, KU Leuven, 2016, 242-311; Niyonkuru, A.-P; 'L'indépendance du pouvoir burundais judiciaire vis-àvis de l'exécutif', 7 African Law Study Library/ Librairie Africaine d'Etudes juridiques, (2011), 1-19; Masabo, M., 'Analyse de l'indépendance de la magistrature au Burundi': Droits et réalités, $O A G$, Bujumbura, June 2011; Rufyikiri, I., 'L'indépendance de la magistrature au Burundi: Bilan et perspectives', Exposé lors d'un atelier organisé par l'Observatoire de l'Action Gouvernementale, Bujumbura, January 2010. Available at: http://justice.gov.bi/IMG/pdf/OAG-_Indep-_magistra ture-_expose.pdf, [last accessed 10 January 2017].

49 Art. 8 of Law No. 1/001 of February 29, 2000 reforming the Status of Burundi's Magistrates, B.O.B (i.e Official Gazette of Burundi), No. 2/2000.

50 Programme d'appui à la Bonne Gouvernance «GUTWARA NEZA», Etudes organisationnelles des directions du Ministère de la Justice, August 2008, 17, ONU- SG- septième rapport du Secrétaire général sur le Bureau intégré des Nations Unies au Burundi (S/2010/608), 30 November $2010,9, \S 44$. 
Regarding appointment, Burundi's Constitution provides that "The President shall appoint career magistrates at the proposal of the minister in charge of Justice, after obtaining opinion of the Superior Council of Magistracy." ${ }^{51}$ However, considering the composition of this latter body, dominated by and biased towards the executive power, despite its constitutional role to guarantee the independency of the judiciary; ${ }^{52}$ the Council is unlikely to correctly fulfil its role. On the contrary, it acts more like a player in a referee's jersey. ${ }^{53}$ Moreover, appointments to some high positions in the judiciary (Constitutional Court, Anti-Corruption Court, Special Court for Land and Other Assets) do not even require an opinion from the Superior Council of Magistracy.

In addition, in the entire judicial structure, there is not a single elected position. All leadership positions (heads and deputy-heads of courts and tribunal, heads and deputyheads of prosecution structures, to name but a few) are filled by presidential decree and ministerial ordinance, in accordance with relevant legal provisions. These leadership positions are very precarious. As is the case with civil servants, heads of courts and tribunals including that of the Supreme Court- as well as all incumbents of leadership positions, there is no term of office legally determined for those positions, leaving theses officials in socalled "ejector seats". As long as they have the confidence of the authorities who appointed them, and who have discretionary competence to remove them from office as well, incumbents of the said positions have much more chance of staying in office for a long time or even to be rewarded with a higher position, but they could easily be removed as well. This uncertainty regarding terms of office for heads of courts and tribunals confers to those authorities who name said positions a strong control over judicial institutions and undue influence in the dispensation of justice.

The security of tenure is known to be one of the basic conditions allowing judges to retain their independence. It is good practice for judges to serve a term of office that is sufficiently long to ensure this independence. After a two-year conclusive probationary training, Burundi's judges are theoretically appointed for life. The 2000 law governing the status of Burundi's magistrates provides that "judges are appointed for life" and that "their carrier ends when they attain the age of sixty-five. " 54 Yet, this latter provision has not been always respected. Without requesting and obtaining their consent and in violation of legal provisions, many judges have been placed on secondment or at another administration's disposal, dismissed before the expiration of their term of office, involuntarily transferred to occupy positions in the prosecution apparatus, etc. By doing so, the executive branch finds a parade to shorten or prematurely terminate the legal tenure of judges. Moreover, for pos-

51 Constitution of the Republic of Burundi, article 222.

52 Constitution of the Republic of Burundi, art. 210.

53 Niyonkuru, A.-P., 'L'accès au juge civil en droit burundais: Approche juridico-institutionnelle', 299-307; Niyonkuru, A.-P; 'L'indépendance du pouvoir burundais judiciaire vis-à-vis de l'exécutif', 10 and 11.

54 Article 21. 
itions for which legislation provides for a fixed term of office, ${ }^{55}$ experiences from the past reveal cases where judges have been dismissed from their function before the expiry of their term of office. ${ }^{56}$

In order to guarantee the independence of the judiciary by preventing judges from arbitrary sanctions from the executive and the legislative branches of government, disciplinary measures should be taken by independent bodies composed of judges or by a majority of judges, and disciplinary proceedings fairly conducted. However, decisions in disciplinary proceedings (leave of absence, suspension, dismissal/removal) are not subject to an independent review, but are decided by the President of the Republic and the Minister of Justice, ${ }^{57}$ if only with the agreement of the Superior Council of the Magistracy (which is, however, a body under full control of the executive). On the other hand, disciplinary sanctions against "rebellious" judges, those who courageously defy illegal orders and instead obey official laws, are common. ${ }^{58}$ In such an environment, judges frequently receive requests from politically influential men, and many prefer bias towards the latter rather than a strict observance of the law. More generally, interference, pressure, instructions and other influences from the executive on the judiciary are made easier by the fact that the institutional mechanism vested with the mission of guaranteeing this independence, namely the Superior Council of the Magistracy, is itself controlled and dominated by the Executive. ${ }^{59}$

Despite the existence of a legal framework proclaiming independence of the judiciary at the highest normative level, the same framework is weakened by gaps and inconsistencies and incoherence with regards to guarantee of genuine independence of the judiciary, particularly from the executive branch of government. In practice, with the judge's career depending on the prince's favour, ${ }^{60}$ which is entirely in the hands of executive authorities, and a Superior Council of Magistracy legally vested with the mission of ensuring a proper func-

55 This is the case for the position of a judge of the Constitutional Court and for the position of Special Court for Land and Other Assets.

56 For example, Presidential Decree No. 100/001/94 of 29 January1994.

572000 Law reforming the Status of Burundi's Magistrates, art. 91.

58 Ntahiraja, B., 'L'indépendance du juge pénal au Burundi: Les défis actuels', KAS African Law Study Library, Vol. 3 (2016), 433; Niyonkuru, A.-P., 'L'accès au juge civil en droit burundais: Approche juridico-institutionnelle', ' 289, 290, 298 (note 1492); Niyonkuru, A.-P; 'L'indépendance du pouvoir burundais judiciaire vis-à-vis de l'exécutif', 8-10.

59 Niyonkuru, A.-P., 'L'accès au juge civil en droit burundais: Approche juridico-institutionnelle', 299-307; Niyonkuru, A.-P; 'L'indépendance du pouvoir burundais judiciaire vis-à-vis de l'exécutif', 10-11.

60 Niyonkuru, A.-P., 'L'accès au juge civil en droit burundais: Approche juridico-institutionnelle' ..., 277-290; Niyonkuru, A.-P; 'L'indépendance du pouvoir burundais judiciaire vis-à-vis de l'exécutif", 6-10; see also Bouka, Y. (Institute for Security Studies), "Status and dynamics of the political situation in Burundi", Central Africa Report, 1 (2014), 9: "The ruling party has also gained control of judicial nominations by influencing the judicial system to neutralise opposition members. The ruling party is often able to arbitrarily arrest opposition leaders on fabricated charges and to then use the courts to legitimize their incarceration.". 
tioning of justice as well as the independence of judges, ${ }^{61}$ but actually dominated by the executive, ${ }^{62}$ political intrusion into the functioning of the judiciary is inevitable, in spite of the courage and integrity of judges. Threats to "rebellious" judges are not limited to their career but extend in some "sensitive" cases to threats to their lives. The case of the former deputy-head of the Burundi's Constitutional Court in 2015, Justice Sylvère Nimpagaritse illustrates this well. It is alleged that he was forced into exile, under death threats from state agents, after he refused to endorse a Constitutional Court ruling allowing Burundi's President Nkurunziza to run for a -controversial- third term in office. ${ }^{63}$ In essence, it is a wellacknowledged fact that without an independent judiciary, the right of access to justice is merely illusory. Lacking independence, the judiciary is unable to perform its constitutional mission of "custodian of rights and public liberties." 64

Regarding the administration of courts, one can notice that Burundi's Judiciary is actually considered as a department of the Ministry of Justice, whereas it should fall under the sole responsibility of the Chief Justice as is the case in countries such as Kenya, ${ }^{65}$ Uganda, ${ }^{66}$ Rwanda ${ }^{67}$ South Sudan ${ }^{68}$ and Tanzania. ${ }^{69}$ Among the East African Community states, Burundi is the only country whose legislation does not clearly provide that the Chief Justice shall be the head of the judiciary and shall be responsible for the administration and supervision of all courts.

Furthermore, the judiciary needs resources for the proper fulfilment of its functions as assigned by laws and rules. "Good Budgeting, Better Justice", said David Webber. ${ }^{70}$ Regarding financial issues, it is important to point out two important challenges: the shortage

61 Constitution of the Republic of Burundi (2005), art. 210.

62 Niyonkuru, A.-P., 'L'accès au juge civil au Burundi: Approche juridico-institutionnelle', 299-307.

63 UN Human Rights Council, Report of the United Nations Independent Investigation on Burundi (UNIIB) established pursuant to Human Rights Council resolution S-24/1, 20 September 2016, A/HRC/33/37, available at: http://www.refworld.org/docid/57e27f274.html [accessed 17 April 2017]; Nimpagaritse, Sylvère, and Gaston Parmentier (2015), Journal d'un juge constitutionnel, in: IWACU, 339, 3-8, online: www.uantwerpen.be/images/uantwerpen/container2673/files/Bu rundi\%20DPP/constitution/Const2005/RCCB303-journal-Sylv\%C3\%A8re.pdf (23 August 2016); Jeune Afrique, 'Burundi: le vice-président de la Cour constitutionnelle dénonce des «pressions» et s'enfuit', http://www.jeuneafrique.com/depeches/231076/politique/burundi-le-vice-president-de-la -cour-constitutionnelle-denonce-des-pressions-et-senfuit/ [last accessed 25 September 2017].

64 Constitution of the Republic of Burundi (2005), art. 60.

65 Constitution of the Republic of Burundi art. 161 (2) (a).

66 Constitution of the Republic of Burundi art. 133 (1) (a).

67 Constitution of the Republic of Burundi art. 140.

68 Constitution of the Republic of Burundi art. 123 (8).

69 Constitution of the Republic of Burundi art. 118 (2.).

70 David Webber, Good Budgeting, Better Justice: Modern Budget Practices for the Judicial Sector, Law \& Development Working Series, no. 3, World Bank. 
of resources on the one hand, ${ }^{71}$ and the lack of budgetary autonomy on the other hand. Since 2009, Burundi's judiciary budget, including expenditures of all services depending on the ministry of Justice have accounted for less than 2 percent of state expenditures, with a general decreasing trend. Compared to other East African states, Burundi's judiciary receives the lowest share of the global national budget.

\section{Allocation to justice sector as a percentage of the total national budget.}

$\begin{array}{llllllllllllll}\text { Year } & 2005 & 2006 & 2007 & 2008 & 2009 & 2010 & 2011 & 2012 & 2013 & 2014 & 2015 & 2016 & 2017 \\ \begin{array}{l}\text { Percent- } \\ \text { age }\end{array} & 1.5 & 1.3 & 2.1 & 2.4 & 1.8 & 1.9 & 1.6 & 1.5 & 1.6 & 1.6 & 1.3 & 1.4 & 1.3\end{array}$

Source: Calculation by the author from Burundi's budget laws.

Burundi's judiciary does not have any opportunity to express its views about the proposed budget to parliament. The central administration under the supervision of the Minister of Justice controls the entire processes of drafting the budget of the Ministry of Justice, including that of courts and tribunals. The judiciary is not required to submit its estimate of its budgetary requirements. Moreover, the Judiciary does not enjoy autonomy over the budget once it is voted. Administration of the budget is performed by the central administration of the Ministry of Justice. The latter is responsible for allotting the judiciary its budget and overseeing its expenditure.

Yet, financial autonomy is known to be the cornerstone of the independence of the judiciary, particularly vis-à-vis the executive and legislative powers. On the dangers of financial dependency of the judiciary, Ugandan principal judge Ogoola stated: "The lack of financial independence whittles down the independence of the Judiciary as an institution. The financial position of the Judiciary had reduced it to a position akin to that of a beggar going cup in hand to the Executive and the Legislative arms of the State in order to be able to perform its constitutional duty." 72 In the same breath, Isidore Rufyikiri, former head of Burundi Bar Association, has pointed out that the lack of financial autonomy by Burundi's Courts "gives the image of a justice that begs and that can consequently be vilified" ("l'image d'une justice qui quémande et qui est conséquemment dénigrable"). ${ }^{73}$ In Burundi's neighbouring country Rwanda, financial autonomy of the judiciary is provided for at the highest normative level. Article 140 para. 3 of 2003 Rwanda's Constitution, as amended to date, states that the judiciary "enjoys financial and administrative autonomy".

71 On the negative impact of Burundi's low budget allowed to the justice sector, see Haburiyakira, F., 'Quand le manque de moyens condamne la justice', Iwacu, 02 November 2017. Available at: http:/ /www.iwacu-burundi.org/quand-le-manque-de-moyens-condamne-la-justice/ [last accessed 2 November 2017]; Masabo, M., Analyse du budget du Ministère de la Justice, $A J C B$ \& CORDAID, Bujumbura, December 2016.

72 Cited by Ellet, R. L., Emerging Judicial Power in Transitional Democraties. Malawi, Tanzania and Uganda, ProQuest, 2008, p. 243.

73 Rufyikiri, I., 'L'indépendance de la magistrature au Burundi: Bilan et perspectives', 7. 
Because of the low budgetary allocation by the state to the judiciary, courts and prosecutorial services suffer several logistical challenges. For example, criminal investigations by the prosecutor's office as well as by police often require, for the purpose of collection and preservation of physical evidence, travelling to the crime scene. Without a physical examination of the crime scene, murders, rapes, thefts, damages to property and other crimes are usually very difficult, if not impossible to adequately investigate. Because such travel costs cannot always be covered, many investigations are botched up, impunity increases because of lack of evidence, while unfair denouncements -in an investigative system primarily based on (eyewitness) testimony- result in trials and sentences against innocent people and so on. When the complainant insists on the necessity of documentation of the crime scene, he or she is asked to pay the taxi fare. ${ }^{74}$ Even in cases when investigators travel to the crime scene, they often lack adequate tools for the collection and transportation of evidence, and when back at their offices, they face the challenge of adequately examining evidence collected; there is a lack of well-equipped forensic laboratories, and most forensic team members are relatively unskilled. To give a picture of the poverty of Burundi's forensic section: it lacks DNA technology at a time when the use of such technology is playing a vital and increasing role in resolving courts cases, particularly but not only in criminal matters.

The problem is quite similar in civil matters. As in criminal matters, some procedures such as the investigation of a case, the demarcation of conflicting land boundaries, and the verification of the enforcement of land-related judgments, require judges and clerks to move out of their offices and perform fieldwork. Here again, litigants are forced to choose between paying "taxi fees" (indéruzo = stretcher) or to wait indefinitely, until the courts find hypothetical funding for their fieldwork. This challenge explains why many final judgments are excessively delayed.

\section{Rule of law versus rulers' law}

\section{"The Rule of Law: Without Trust It Fails".}

Franklin, $\mathrm{H.}^{75}$

Human rights and the rule of law are inseparable; the latter being a fundamental pillar of the former. The concept of the rule of law is embedded in Burundi's legal framework. Since the so-called third wave of democratisation began to roll across sub-Saharan Africa in the early 1990s, Burundi has initiated legal and institutional reforms aimed at building a society ruled by law. For the first time, the Burundi's Constitution of 13 March 1992 proclaimed

74 In a 2016 survey on access to justice in Burundi (AJCB, CORDAID), investigative police officers (officiers de police judiciaire) confirmed what is well-known in public opinion.

75 Franklin, H., 'The Rule of Law: Without Trust It Fails', http://howardgfranklin.com/rule-law-with out-trust-fails/[accessed on 19 February 2018]. 
the need to establish the rule of law. ${ }^{76}$ All the Constitutions that followed as well as other texts with a constitutional legal value enacted since, endorsed the principle of rule of law.

As far as the protection of human rights is concerned, a quick overview of Burundi's legal framework shows some merits which could provide foundation for domestic mechanisms of protection - and promotion - of human rights. Achieving such protection and promotion requires, however, a universal trust in the rule of law; a society where institutions and their leaders, individuals and corporations, big men and ordinary people, are subject to and accountable to law. Without such a society, neither a comprehensive legal framework nor a perfect human rights institutional design, can in any way guarantee the effectiveness of judicial protection of human rights.

Critically, Burundi lacks an engrained culture and practice of the rule of law. When the practice of the rule of law was being tried out, particularly during the post-transition period after 2005, the 2015 political crisis erupted, disrupting the experiment. But more generally, even before this crisis broke out, the country was characterized by a major gap between theoretical - legal - provisions and their practical implementation, in the fields of both human rights and the rule of law. Thus, ordinary people remain frustrated with situations they witness or experience in day-to-day life, which demonstrate significant discrepancy between law in the books (law as written in Codes et Lois) and law-in-action; even though the degree of comprehensiveness and of compliance with international standards of the former constitute, per se, a solid legal framework for the - judicial - protection of - fundamental human rights and freedoms.

Whereas according to Burundi's laws, - including the Constitution - judicial power is vested in the judiciary, ${ }^{77}$ such that "the judiciary shall be impartial and independent from the legislative and the executive branches of the government"78 and "judges shall be subject only to the Constitution and the law", ${ }^{79}$ in practice, during the exercise of their constitutional duties, Burundi's judges sometimes face embarrassing normative challenge. When it comes to the so-called - politically - "sensitive files" or "sensitive cases" (dossiers sensibles), the rulers' law takes its revenge on the rule of law. The expressions "sensitive cases", "sensitive issues" or "sensitive files" encompass a broad range of judicial proceedings, mostly criminal proceedings, including but not limited to, human violations by state security services (government army, police, intelligence agencies, etc.) and by ruling party officials. When these categories of people are alleged to be perpetrators of human rights abuses, many observers believe those responsible for such violations go unpunished. ${ }^{80}$ During

76 Preamble to the Constitution, 1992.

77 Constitution of the Republic of Burundi, article 205.

78 Constitution of the Republic of Burundi, article 209, para.1.

79 Constitution of the Republic of Burundi, article 209, para.2.

80 See, inter alia, Human Rights Watch, World Report 2015, Events of 2014, 128. On the impunity enjoyed by the ruling party youth (Imbonerakure), see among others, 'Burundi: Locked down. A Shrinking of Political Space', Amnesty International, July 2014, 5, 26; Gakunzi, D., 'Burundi : 
his oral briefing, on March 13, 2017 to the UN Human Rights Council, Fatsah Ouguergouz, Chair of the Commission of Inquiry on Burundi stated:

"We are particularly concerned by the near-complete impunity enjoyed by those responsible for these violations. Even when victims or witnesses are able to identify suspected perpetrators, cases of prosecution of state agents, or those who appear to have their support, are rare." 81

Burundi's people harbour no illusions. In settling sensitive cases, most judges will obey what is cynically or ironically referred to as "instructions coming from the top" or "orders from "high up" (ordres venant d'en haut). On this phenomenon, Jill Craig contends that "there is a complete loss of confidence, in law enforcement, in the judiciary, because any politically sensitive cases are going to be led by ruling party policies". ${ }^{82}$ To cap it all, the lawless area extends beyond the limited cases of "sensitive files". Taking advantage of situations where judicial authorities are not able to identify with certainty the origin of "instructions", some people falsely impersonate powerful men in the state structures or influential personalities in the ruling party apparatus or present themselves as representatives of one or another, in an attempt to obtain from the judicial mechanism a biased decision in their own interest.

Apart from political interference into the judiciary and other intrusion by people inspiring fear by utilizing their annoyance capacity, Burundi's judiciary has the "reputation" of being hindered by corruption. The degree of corruption within the country's judicial system

'Comment rendre justice lorsque l'État est l'instigateur des crimes?', Jeune Afrique, November 22, 2017. Available at: http://www.jeuneafrique.com/495489/societe/burundi-comment-rendre-justicelorsque-letat-est-linstigateur-des-crimes/ [last accessed 27 November 2017].

81 HTTP://WWW.OHCHR.ORG/EN/NEWSEVENTS/PAGES/DISPLAYNEWS.ASPX?NEWSID= 21361\&LANGID=E (last accessed 25 October 2017).

82 Craig, J.; 'HRW: Ruling Party Youth Responsible for Violence Across Burundi', VOA Africa, January 19, 2017. Available at https://www.voanews.com/a/hrw-ruling-party-youth-responsible-for-vi olence-across-burundi/3683444.html [last accessed 16 November 2017]. 
is of such magnitude that it has been labelled a "scourge", 83 "gangrene", 84 "cancer", 85 and "headache" in Burundi's judicial sector; 86 all anything but flattering terms. Mathijs van Leeuwen and Linda Haartsen went so far as to state that "to win a case, you need to have money" ${ }^{87}$ A quote by the French comedian Coluche describes Burundian reality quite well: "There are two types of lawyers: those who know the law well, and those who know the judge", 88 or as the saying goes "good lawyers know the law, great lawyers know the judge." ${ }^{89}$ One may even go so far as to say that the best lawyer is the judge handling your case. Situations of "bought judges" are likely to happen in Burundi, despite a series of legal and institutional reforms adopted over the last decade and aimed at preventing and combating corruption. ${ }^{90}$ Though not the only cause, low salaries paid to judges and to other judicial staff are believed to be the main reason for the widespread corruption in the judiciary. This section does not aim, however to deeply address the question of corruption within Burundi's judicial system. Neither its causes, its forms, nor any other aspects have been particularly focused on. It has aimed only at stressing the massive threat to the rule of law, to equal and effective access to justice and to judicial protection of human rights that corruption represents in Burundi.

Last but not least, as far as the question of rule of law with respect to judicial protection of human rights is concerned, while it is recognized that in a state governed by the rule of

83 Sebudandi, Chr., 'Au Burundi, la corruption augmente et touche tous les secteurs', Dépêche No. 38, Gladis/Afro Baromètre, 12 July 2015; Nkengurutse, Au., Kubwimana, V., Ndikumasabo, V., 'Etude diagnostique du système juridique et judiciaire du Burundi', Projet d'Appui à la Gestion Économique (PAGE), Africa Label Group, Final Report, April 2009; Nkengurutse, Au., Kubwimana, V. and Ndikumasabo, V., 'Analyse.documentaire préalable à la réalisation de l'étude diagnostique du système juridique et judiciaire du Burundi', Projet d'Appui à la Gestion Économique (PAGE), Africa Label Group, Final Report, May 2008.

84 Kohlhagen, D., 'Burundi : La justice en milieu rural', RCN Justice \& Démocratie, Bujumbura, December 2009; République du Burundi, Ministère à la Présidence Chargé de la Bonne Gouvernance, de la Privatisation, de l'Inspection Générale de l'Etat et de l'Administration Locale, 'Etude diagnostique sur la gouvernance et la corruption au Burundi', Survey Report, Bujumbura, May 2008.

85 'Pierre Nkurunziza: «Les travaux communautaires ont sauvé le Burundi»', Ikiriho, 13 February, 2017. Available at: http://www.ikiriho.org/2017/02/13/president-pierre-nkurunziza-les-travaux-co mmunautaires-ont-sauve-le-burundi-histoire-medias-ikibiri-colonisation-dictature-elites-monde-ru ral-afrique/ [last accessed 25 October 2017].

86 Shinichi Takeuchi, Confronting Land and Property Problems for Peace, Routledge, 2014, 118.

87 Mathijs van Leeuwen and Linda Haartsen, Land conflicts and local conflict resolution mechanisms in Burundi, A research for CED-CARITAS Burundi Final, complete English version Bujumbura/ Wageningen November 2005, 46.

88 «Il y a deux sortes de justice: vous avez l'avocat qui connait bien la loi, et l'avocat qui connait bien le juge » (Coluche, L'Almanach, Le Cherche Midi, 2015).

89 Ray W. Rowney, Jr., License to Steal: Truth and Justice are Inseparable, Xlibris Corporation, 2012; Lee Cody, The 14th Denial, Lulu.com, 2010.

90 Niyonkuru, A.-P., 'La Cour anti-corruption du Burundi: Quand la question de compétence se pose en sens inverses', 16 African Law Study Library/Librairie Africaine d'Etudes juridiques, 2013, $35-45$. 
law, the administration is neither entitled to exercise the judicial power legally vested in courts, ${ }^{91}$ nor allowed to substitute its own decisions for court judgments nor to obstruct the enforcement of those judgments anyway; nonetheless, a review of the - legal - literature reveals cases of undue interference from public administrators undermining the enforcement of courts decisions. ${ }^{92}$ This behaviour, which represents one of the manifestations of the climate of lawlessness prevailing in Burundi, constitutes a serious challenge to judicial protection of human rights and effective redress for grievances. The effective enforcement of courts decisions is of such importance that winning in court and lacking the benefits of the court's judgment is meaningless. The European Commission for the Efficiency of Justice rightly held, in 2014 that "there is no real access to justice if court decisions are not enforced in order to produce the expected results", and also that "the right to proper administration of justice implies that the enforcement of court decisions should itself be effective and efficient." ${ }^{93}$ In the same vein, the African Commission on Human and Peoples' Rights in the case Bissangou $v$ Republic of Congo, has stated that "the right to be heard guaranteed by article 7 of the African Charter includes the right to the execution of a judgment. It would therefore be inconceivable for this article to grant the right for an individual to bring an appeal before all the national courts in relation to any act violating the fundamental rights without guaranteeing the execution of judicial rulings. To interpret article 14 [of the ICCPR] any other way would lead to situations which are incompatible with the rule of law. As a result, the execution of a final judgment passed by a tribunal or legal court should be considered as an integral part of 'the right to be heard' which is protected by article 7."94

To conclude, it is important to stress that the results of various enquiries on access to justice indicate that people feel themselves governed by the rulers' law rather than the rule of law. The state of lawlessness observed in dispensation of justice prevents victims for human rights abuses from accessing justice and obtaining reparation through the domestic courts.

91 Constitution of the Republic of Burundi, article 205.

92 On the problem of enforcement of court decisions in civil matters, see Niyonkuru, A.-P., 'L'exécution des jugements civils au Burundi: Incohérence normative, pratique à la limite de la légalité, ver dans le fruit', KAS African Law Study Library, Vol. 3 (2016), 405-423.

93 Lhuillier, J. et al., Enforcement of Court Decisions in Europe, Report prepared by the Research Team on enforcement of court decisions (University Nancy (France) / Swiss Institute of comparative law) and discussed by the CEPEJ-GT-EVAL at their $8^{\text {th }}$ meeting, European Commission for the Efficiency of Justice (CEPEJ), 2014.

94 Bissangou v Republic of Congo (2006) AHRLR 80 (ACHPR 2006), Communication 253/2002, Antoine Bissangou v Republic of Congo, Decided at the 40th ordinary session, November 2006, 21 st Activity Report, para. 75. 


\section{A judicial passivism: Missed opportunities in the judicialization of international human rights law}

The constitutional incorporation of international human rights instruments empowers domestic courts with a potential and even a duty to activate these instruments and interpret their provisions, particularly when they are incorporated into domestic law. However, despite a non-contested monist legal system and a legal framework where international human rights are fully domesticated, Burundi's judges show significant reluctance to apply provisions contained in international human rights instruments. This hesitancy or refusal to apply what they falsely consider as international law even when parties to a court-case or their lawyers rightly invoke domesticated international human rights law provisions, hampers the protective potential of a progressive human rights framework. In the end, neither the ratifying of human rights treaties nor their domestication seems to have significantly improved respect for human rights on the ground. Without disowning comments made in the previous section with respect to challenges to the judicial protection of human rights in - post-conflict - Burundi, I suggest here that this "paradox of empty promises" gal framework is essentially due to judicial passivity with respect to application of the domesticated international human rights law.

The hesitancy or unwillingness to apply "international" human rights norms in domestic cases despite an explicit constitutional provision that recognizes international human rights instruments, particularly in their provisions proclaiming and guaranteeing human rights as national law limits the benefits normally attached to the ratification of human rights treaties and to their domestication. Over decades, Burundi's judges have missed great opportunities to use a progressive human rights legal framework, which further embeds into domestic law the human rights enshrined in international human rights instruments, to significantly contribute to the development of human rights adjudication. One example, chosen among many others, illustrates this passivity. It relates to a woman's rights to equality and non-discrimination with respect to inheritance. Thus far, in inheritance-related litigation, Burundi's courts continue to issue judgements which deny women land rights on the grounds of both contested "customary laws" and in contradiction to the Constitution and international human rights instruments where women's rights, including the equality of rights between men and women, are directly incorporated into and made an integral part of national law. ${ }^{96}$ Litigants may argue, in demanding the application of provisions of international human rights instruments, that the said provisions are an integral part of Burundi's Constitution and that they have been transformed into national law. Judges, however, - except the Constitutional Court - will rarely agree to discuss arguments based on these provisions or to refer to or rely on them in their judgments.

95 On this concept, see: Hafner-Burton, E.-M. and Tsutsui, K., 'Human Rights in a Globalizing World: The

Paradox of Empty Promises', 110 American Journal of Sociology, 5 (2005), 1373-1411.

96 By virtue of article 19 of the Burundi's Constitution of 2005. 
This tendency of the courts to summarily dismiss arguments based on international human rights law and their reluctance to find violations of this law are rather a consequence of lack of familiarity with the rules of the game with respect to direct applicability and incorporation of treaties in the domestic legal order than judicial unwillingness to enforce constitutional rights. The legal educational background of most of Burundi's judicial personnel, including judges, is not likely to sufficiently prepare them for the effective interpretation of international human rights instruments and their application in a domestic context. Still, human rights issues are part of the law school curriculum. The amount of time allocated for issues relating to human rights accounts for a negligible share, however, compared to that of some other key courses (civil law, criminal law, administrative law, etc.). Moreover, this insufficiency extends to continuing education and training programmes supported by the Training Centre for Justice System Personnel (Centre de Formation professionnelle de la Justice).

Siniša Rodin and Tamara Perišin listed reasons for the rare application of international human rights in the case of Germany, points which are more relevant with regard to Burundi's judges:

"1. International human rights norms are not part of the core curricula in the legal education and practical training of lawyers and judges.

2. Some courts may have difficulties in obtaining (...) translation.

3. Access to texts of international norms sometimes proves to be difficult." 97

It is worth noting that, occasionally, courts in Burundi have stressed the importance of the ratification of international human rights instruments in protecting human rights, emphasizing this latter. In one of his judgements, Burundi's Court of Cassation stated that "since the ratification of these two international legal instrument, courts endorsed special responsibility to ensure respect for the principle of gender equality by preventing their decisions from unequal bias based upon ancestral practices. $" 98$

Beyond enhancing protection of human rights through applying those international human rights provisions duly and fully embedded in national law, with a minimum of voluntarism and without fearing any serious accusation of judicial activism, ${ }^{99}$ Burundi's judges could draw inspiration from jurisprudence and precedents of the universal and regional hu-

97 Siniša Rodin and Tamara Perišin, Judicial Application of International Law in Southeast Europe, Springer, 24 April 2015, 193.

98 RCC 10351, Judgement of 11 January, 2005.

99 On this concept, its myth, its reality, the fear it inspires to some, and the hope to others, see among others Calvès, G., 'Un juge qui gouverne? La question de l'activisme judiciaire', Lacorne D. (ed.), Les Etats-Unis, Paris, Fayard et CERI, 2006, 87-101; Keenan D. Kmiec, The Origin and Current Meanings of Judicial Activism, 92 Cal. L. Rev. 1441 (2004). Available at: http://scholarship.law.be rkeley.edu/californialawreview/vol92/iss5/4; Vandycke, R., 'L'activisme judiciaire et les droits de la personne : émergence d'un nouveau savoir-pouvoir?', 30 Les Cahiers de droit, 4 (1989), 927; Perrot, R., 'Les pouvoirs du juge dans le procès civil', Revue de Droit International et de Droit comparé.,1973-74,7-28; Wolfe, Chr., Judicial Activism: Bulwark of Freedom Or Precarious Secu- 
man rights mechanisms, which have contributed to the development of human rights through their interpretation of international human rights law. This requires, however, a certain level of skills in international human rights law; skills that, unfortunately, many judges lack. Worse, judges lack access to documentary resources. Rare are the courts which are equipped with a library. For those with libraries, these latter are often poorly equipped. Last but not least, a great majority of judges and court staff do not have access to the internet. All of these challenges limit development by Burundi's courts of a creative and robust human rights jurisprudence.

\section{Concluding remarks}

This paper has dealt with the protection of human rights in - post-conflict - Burundi, with a particular focus on major challenges faced by the judicial mechanism in performing its constitutional role of guardian of human rights and freedoms.

The discussion has shown the insufficiency of an approach limited to solely legal aspects for a comprehensive addressing of the issue. Accordingly, while pointing out the importance of a progressive, coherent legal and institutional framework, which strongly complies with relevant international standards, the paper has demonstrated, with respect to institutional mechanisms for human rights protection in Burundi in general, and the judiciary in particular, that the biggest challenge hardly consists of a legal vacuum or insufficiencies.

Still, as far as Burundi's legal and institutional framework for protection of human rights is concerned, this reflection acknowledges that there is still room for improvement. This improvement can be achieved by undertaking a comprehensive review and relevant reforms of the national legislation, to ensure its full compliance with international standards.

In addition to this, however, a major challenge remains that the potential of the existing legal framework for the protection of human rights remains largely under-used by courts and law enforcement agencies. Most of the human rights abuses reported to have been committed in -post-conflict- Burundi, thus far, constitute crimes under Burundi law. The impunity that perpetrators of violations are alleged to enjoy; the illegal practices against women in which courts decline to find discrimination, the failure in judicial control of lawfulness of arrests, search, and detention; the allegations that courts have failed to implement procedural sanctions against evidence secured by illicit means, including torture, namely the non-admissibility of such evidence: these are not basically consequence of improper legal framework.

On the contrary, this paper has found that rather than any vacuum or insufficiency in the legal framework, the major challenges to effective judicial protection of human rights in post-conflict - Burundi can be attributed to the lack of independence of the judiciary, which is incapable of holding accountable those responsible for human rights violations and abus-

rity?, Rowman and Littlefield, 1997; Canon, Br.-C, "Defining the Dimensions of Judicial Activism", 66 Judicature 236 (1983). 
es, ${ }^{100}$ the weaknesses in the rule of law, and also the passivity of Burundi's judges who fail to exploit the full and great potential of the existing legal framework to translate human rights law into practice.

Material, political and educational conditions are all unfavorable as we have seen. In this perspective, the legacies of protracted conflict in Burundi still have not been overcome.

Above all, connecting practice to those principles proudly proclaimed into laws remains the biggest challenges to effective - judicial- protection of human rights in - post-conflict Burundi.

100 Particularly when authors of these violations and abuses are, or include, state organs, entities empowered to exercise elements of the government authority, or persons acting in fact on behalf of the State. 